\title{
An Analysis of Mark Twain's Ecological Narratives
}

\author{
Liu Yan ${ }^{1}$ \\ ${ }^{1}$ School of Foreign Languages, Yancheng Normal University, Yancheng, China \\ Correspondence: Liu Yan, chool of Foreign Languages, Yancheng Normal University, Yancheng, China. E-mail: \\ hobbyc@163.com
}

Received: August 30, 2021

Accepted: October 3, 2021

Online Published: November 4, 2021

doi:10.5539/ells.v11n4p56

URL: https://doi.org/10.5539/ells.v11n4p56

\begin{abstract}
American writer Mark Twain has witnessed changes of American environment of the 19th century, which changes his sense of place. Urbanization and industrialization separate human beings from nature, leading to various conflicts. City is always regarded as the symbol of order, reason, crime and degeneration, while nature means freedom and happiness. Twain advocates the return to nature to lead a simple life. He tries to reveal the ecological crisis in the 19th century and express his ecological concepts through redefining "place", "space" and son on.
\end{abstract}

Keywords: Mark Twain, ecological narratives, place

\section{Introduction}

The ecological narrative is a narrative technique based on "ecosystem", which combines the overall value and benefits of ecological environment. As a kind of literary creation, the appearance of the ecological narrative is a response to damages to nature caused by industrial civilization.

After the American Civil War, the romantic literature was gradually replaced by the realistic literature. As a representative writer of this period, Mark Twain describes the crisis in the so called "the Gilded Age" with his keen vision and humorous language. His works draws the social picture of the Midwest of the United States in the 19th century and also discusses damages to the environment. On the one hand, Mark Twain is deeply in the nostalgia of the past golden times on the Mississippi river. On the other hand, he laments the hypocrisy, dirtiness and moral degeneration brought by urbanization and industrialization. By constructing a series of ecological metaphors in the works, Twain calls for the return to nature. Meanwhile, he asks to purify people's soul in nature so that the modern people can adapt to the new environment with the ecological awakening. His writing is actually an ecological narrative to make a positive response to the environmental crisis in the 19th century.

This paper is going to systematically discuss Mark Twain's ecological narrative from two sides: Mark Twain's confusion about modern civilization and his calling for the return to nature for the spiritual salvation. This paper points out the Mississippi river as a significant symbol to interpret the multiple dimensions of Twain's ecological narrative under the framework of material narration. In fact, the Mississippi river stands for the whole nature to console Twain's sorrow about the lost golden memories and worries about great environmental changes in the Midwest of America.

\section{Literature Review}

Mark Twain is always regarded as a realist writer by many scholars because he has described the social changes vividly and truly. From the 20th century to the 21st century, the major feature of Mark Twain's research in this period is to break through a single literary investigation and form a multiple sociological criticism system which includes such as anthropological criticism and cultural research.

In terms of the sociological studies, Aaron Derosa points out Mark Twain is influenced by the social Darwinism which believes that fittest survive in the society just like in nature. Some protagonists such as Huck and Tom would make different choices when they are in nature. Mark Twain always has to struggle between "biological instincts and learned behaviors but failed to come up with a convincing theory of cultural evolution" (Derosa, 2012, p. 159). Linda Nash claims that in Life on the Mississippi, Mark Twain expresses his technological and ecological knowledge about rivers. However, Twain still shows his naive response to nature. He regards nature only as beautiful landscapes form the perspective of anthropocentrism. Dewey Ganzel points out that Mark 
Twain is good at using different resources of information to describe the environmental changes along the Mississippi river. Robert Douglas believes that in Twain's works, there exists pessimism which shows Twain's attitude towards the social injustice, distorted family bound and social order. In fact, these problems are often linked with the industrial and commercial process in the 19th century. Creghton Lindsay advocates that in Twain's works, nature is close to human beings, not modern technology such as steamboats. Nature owns "its characteristic state of grace and beauty. Twain's Mississippi seems an appropriate metaphor for this cri-tique of America's heady industrialism" (Lindsay, 1996, p. 78). And a few scholars pay attention to the canonization of Twain's novels. They argue that Twain's works is a heritage of American traditional culture.

Actually, Twain has noticed the ecological crisis and the environmental changes in his period. Some scholars have begun to analyze the ecological ideas in Twain's works. They argue that Mark Twain's literary works all reflect the relationships between man and nature, society and people. Twain advocates of nature, democracy, freedom and peace. At the same time, it is Mark Twain progressive thoughts which is consistent with times that distinguish him from his peers during his period. Pan Ming points out that Twain has expressed his anti-anthropocentrism and desire to find the harmony between human beings and nature (Pan, 2014, p. 100).

However, his ecological concepts and narratives still need more comprehensive studies. This paper focuses on Twain's attitude towards the modern civilization and his strong will to return to nature, pointing out that to some extent, the rapid economic and technological development can not bring prosperity, but leads to the ecological damage and the spiritual alienation.

\section{An Analysis of Mark Twain's Ecological Narratives}

\subsection{The Confusion about Modern Civilization}

On September 6, 1620, Mayflower sailed from Plymouth to the new continent of North America carrying 102 pilgrims who try to establish a new "Garden of Eden". These Puritans initially intend to establish a harmonious relationship with nature on this land. From the initial praise and awe of nature to the conquest of nature, the relationship between nature and mankind has always been a focus of in many American writers' works. American historian Turner once points out that "the western frontier is the extremely important factor for the development and formation of American national character. Here, culture and nature converge, and different environments gradually transform various European cultures into real American culture and identity" (Smith, 1991, vol. 2). Furthermore, Henry Nash Smith believes that everything in nature is beautiful, while civilization especially the modern urban civilization is full of corruption. The understanding of contradictions between nature and various civilizations is the key to interpreting these American Empire myths and garden myths.

Mark Twain once worked as a sailor and went through the whole Mississippi river. This experience provides writing materials and a great chance to observe environmental changes. Twain has a deep deep understanding of his environment where he lives and works. He takes the western America as the object, and truly reproduces the process of the American ecological environment in the 19th century. On the one hand, he is nostalgic for the past sweet times in the western United States; on the other hand, he condemns the deterioration of the environment and the decline of morality in the western United States at that time. He criticizes damages brought by the so-called "civilization" to nature. Through describing the great changes in the environment and society in the western United States under the industrial civilization, Twain reveals kinds of crises hidden in the 19th century.

Since the 19th century, with the historical process of industrial revolution, great changes have taken place in the western United States. The rapid growth of population, urbanization, ethnic problems and environmental damage lead to a new value such as pragmatism. In the Adventures of Huckleberry Finn, Mark Twain focuses on the Mississippi river. The Mississippi River is not only the material basis on which human life depends, but also the carrier of human spirit and culture. Mark Twain has a natural closeness to the Mississippi River. He was born in Hannibal, a small town on the Mississippi River. After dropping out of school, he works as a printer and sailor. Later, he is renamed "Mark Twain", which means "water depth of 12 feet". The sailor's experience provided him with rich life experience and Mississippi River often appears in her works. The Image of river becomes the spiritual resource of Mark Twain's memory and imagination. In Life on the Mississippi, Twain recalls that his hometown Hannibal is a white town which is silent bathed in the summer morning sunshine. The mighty and majestic Mississippi River, carrying a wave nearly one kilometer wide, pours down. The Mississippi River brings him peace and romance. It also becomes the place where protagonists such as Huck grow up in the works.

Mark Twain often played on his uncle's farm in his childhood. The fresh nature, the singing of birds and the fragrance of flowers and countless fruits have become his beautiful memory. In his works, he describes the smell of soil and the fragrance of flowers and plants, as well as the glittering leaves after the rain, the sound of the breeze blowing through the rain, the sound of woodpeckers pecking trees in the woods and the deep cry of 
pheasants in the grass. The rich work experience in adulthood made Mark Twain closer to nature. He formed a close relationship with the Mississippi River. He points out that the Mississippi River occasionally turns into a moving picture album. For passengers who don't have the ability to appreciate it, it has no beauty. But Twain can appreciate its mystery and feel its meaning very clearly. He is in great awe of the Mississippi River.

But the industrial and urban process breaks the peace of the Mississippi river. In his many works, Twain pays attention to changes of nature caused by the industrial process. In many small towns such as his hometown Hannibal his quiet and the air is fresh and quiet. The fragrance of flowers is diffused in the breeze. There is the buzzing of bees in the air and the leisure and tranquility brought by the summer forest. You can see pine forest, wheat field, corn field, iron ore, copper mine and coal mine. The West looks like a holy place where everything seems so quiet, and the past sweet pastoral time in the West seems to continue.

Actually, driven by the desire for wealth, this small town has become the unlimited business opportunities. The whole town is dilapidated and lifeless. The vessel is like "a fierce eye with fire, and the light is much fiercer" (Twain, 2002, p. 27). The industrial economy has replaced the agricultural economy. Nature has been swallowed up by industry, and the social atmosphere is boastful. Everyone dreams of making a fortune, but refuses to be hard-working and opportunistic. In the end, everything turns out tot be illusory. Lies, fraud, corruption and indifference change the western United States. There are no longer beautiful mountains and rivers, but the target of the commercial investment. Human beings grab natural resources madly for economic interests, and nature falls a victim to industrial civilization. "The foundation began to collapse along the bank of the river, bit by bit into the river. In only one summer, the whole foundation fell into the river. A small town like that has to move back and forth endlessly, because the river always gnaws at it" (Twain, 2002, p. 149). Great changes have taken place in nature. Soil erosion, pollution and overpopulation have led to a serious ecological crisis.

In his masterpieces, such as The Adventures of Huckleberry Finn, The Adventures of Tom Sawyer, The Gilded Age, The 1,000,000 Bank-Note, Mark Twain all expresses his worries and confusion about the modern civilization. The development of modern industry does not bring fantasy to Twain. On the contrary, he regards the modern technology as a frightening monster. He believes that the modern science and technology have changes nature. In Twain's works, steamships which sail along the river like a ghost. It screams like a ghost to stir the whole quiet life. These machines are often ridiculous under Twain's pen. He describes the beautiful garden, high building, the sprang of numerous factories, the expansion of population and the development of traffic. In his work Life on the Mississippi, he once describes the chaos in the Helena city. Streets are dirty and full of mud. Ponds with malaria bacteria can be seen everywhere. The whole city is lifeless and boring. He also mentions that the ship "Bronze powder" exploded in Kentucky state and 57 people were hurt or dead. In reality, Twain admits that industry indeed influences each aspect of people's life. But what bothers him is the alienation between people and the disappearance of past quiet life in such a modern world. He has been trying to find solutions to all social problems and nature is his answer.

Nature is both a partner and a mother for all things. Mark Twain is also beneficial to the European continent, Australia and other places. He is amazed by the different natural scenery. He wrote five travel notes, such as $A$ Tramd Abroad (1880), Life on the Mississippi River (1883) and Following the Equator (1897). With his contact with nature, Mark Twain realizes the importance of nature and laments damages of industrial civilization to the environment, so that he could represent the ecological crisis truly. This positive ecological concept has also become an important element in his works.

\subsection{The Spiritual Salvation in Nature}

Mark Twain's hometown Hannibal is a small town which is located in the Missouri state. Once you walk into this town, you can see the forest and hear the murmuring of the Mississippi river. The quiet life and beautiful landscape impressed young Mark Twain. Human beings and nature are in harmony. In 1853, Twain moved to big cities and worked in a factory. The modern life in cities make him often remind of his hometown. Bushes, wild flowers, caves and rivers there all become Twain's unforgotten memories. Twain regards nature as a place where people can find a kind of comfort and a sense of belongings. He thinks human beings can realize their spiritual redemption in nature. Goodness in the human nature can defeat evil if a man can take a trip in nature. This is the reason why Twain describes many adventures in nature, such Tom's and Huck's. These characters grow up and discover the most valuable quality in human nature.

Through Huck's journey on the Mississippi river, Twain reveals the ecological crisis and calls for the self-salvation. Huck's river trip is not only a survey of the ecological environment of the western United States, but also a purification of his soul. The river flows slowly, taking away the hypocrisy and sin of the world, in sharp contrast to the struggle for fame and wealth on the shore. Huck once thought, "it's fun to live on a raft. 
Above our heads is the sky. The sky is full of stars. We always lie on our backs on the raft and look at the stars" (Twain, 2014, p. 123). Huck, with his pure nature, returns to the embrace of nature and escapes from industrial and urban civilization. Nature has become Huck's most loyal partner and his ideal residence. From the initial shelter to a close friend, Huck's attitude towards nature has changed. Huck wants to catch birds, and Jim says that the birds would die, so Huck gives up. On the Mississippi river, Huck feels that a refreshing breeze blows up and gently blows at you from the other bank. It's really cool and the smell is very fragrant. The air smells good. He begins to realize the comfort that nature brought to his soul, paying attention to the destruction of nature by human beings. He witnesses that someone throws some dead fish everywhere, such as long billed fish, which smells like hell. The river trip makes Huck fully feel the nature, and nature becomes a paradise opposite to the small town in the novel. Therefore, Huck believes that river is best to take the raft as a home. Other places look awkward and sulky, but like not on the raft. When you sit on the raft, you feel very free, happy and comfortable. When Jim and he drift down the river, and they are free again. There are only two of them on the river, and no one will make trouble. Only in nature can human beings release their stress and anxiety, to find their value, getting rid of secular rules. They are far from the spiritual alienation and realize real freedom.

The riverside life in The Adventures of Huckleberry Finn is in sharp contrast to the natural life of the Mississippi river. As another main clue in the novel, this sharp contrast runs through the story. As the opposite of free life, the riverside life is full of violence, crime, lies and naked money transactions. In Mark Twain's works, the social civilization is ugly. The world is cool and intriguing, which makes readers feel changes brought by the industrial civilization and commercial capital. The riverside life is not a thriving scene but it is full of dwellings like dwarfs, muddy streets shared by people and animals, pigs and dogs running around. Aristocrats' corrupt life and racism make people be indifferent and numb to each other. Huck's father is an alcoholic, cold and rough, and often beats Huck. Huck recalls that but his dad beats him all the time. He can't stand it. His whole body is full of whip marks. His father's maltreatment on him makes Huck can only seek comfort from nature. The river provides Huck with material and spiritual wealth and becomes his friend. "There is floating bread on the river. You can also pick some fish from the fishing hook and make a hot breakfast. You can hear the violin or singing from one of the boats..." (Chen, 2013, p. 15). In his father's eyes, Huck is a naughty boy, which casts a shadow over the child's young heart. The Mississippi River is like a loving parent, with beautiful scenery, harmony of all things and the fragrance of birds and flowers. Huck and Jim are on the river, they can swing their legs in the water and talk all over the world for a long time whether at day or night. They are are always naked, because clothes are really uncomfortable to wear on them. The closeness to nature just reflects the gap between father and son in the riverside life.

Through the river trip, Huck not only find a true friend Jim, but also get his mentor in nature. He gradually discovers the social evil and grow into a "son of nature". Huck initially suspects that his help slaves to escape is wrong. However, when he is with Jim, he cherishes the happy time, the friendship between them, and Jim's concern for himself. Huck witnesses the crime of swindlers, the violence on the shore, the temptation of gold coins and the hypocrisy of everyone, he gradually realizes the value of Jim's quality. He finds the spiritual power given by nature, and accomplish his spiritual salvation.

\section{Conclusion}

Since the 19th century, the American economy grew sharply, the Westward Movement and "the Gold Rush" have greatly expanded the territory of the United States whereas the environment is being jeopardized. Mark Twain has paid much attention the ecological changes with his keen vision. He criticizes the confusion and hesitation brought by the modern civilization, while he calls on mankind to return to nature and purify their soul. His ecological narrative is not only a language experiment such as to use various ecological metaphors, but also a illustration of his ecological narrative strategy.

\section{Acknowledgements}

This work is supported by the Philosophy and Social Sciences Research Foundation Project of Jiangsu Higher Education Institutions (NO. 20WWB007).

\section{References}

Chen, Y. L. (2013). The Image of Rivers. Chongqing: Chongqing Normal University.

Derosa, A. (2012). Europe, Darwin, and the Escape from Huckleberry Finn. American Literary Realism, 2, 157-173. https://doi.org/10.5406/amerlitereal.44.2.0157

Douglas, R. (1951). The Pessimism of Mark Twain. Mark Twain Quarterly, 1, 1-4.

Ganzel, D. (1962). Twain, Travel Books, and Life on the Mississippi. American Literature, 1, 40-55. 
https://doi.org/10.2307/2922244

Henry, N. S. (1991). Virgin Land (Xue Fankang and Fei Hanzhang Trans.). Shanghai: Shanghai Educational Publishing House.

Lindsay, C. (1996). Rhetoric, Ideology, and Twain's River. Interdisciplinary Studies in Literature and Environment, 2, 73-84. https://doi.org/10.1093/isle/3.2.73

Nash, L. (2000). The Changing Experience of Nature: Historical Encounters with a Northwest River. The Journal of American History, 4, 1600-1629. https://doi.org/10.2307/2567579

Pan, M. (2014). An Eco-critical Interpretation of The Adventures of Tom Sawyer. Yi Chun College Journal, 11, $100-103$.

Twain, M. (2002). The Gilded Age. Zhang Yousong Trans. Shijiazhuang: Hebei Education Press.

Twain, M. (2014). The Adventures of Huckle Finn (Pan Qingling Trans.). Beijing: Beijing United Publishing House.

\section{Copyrights}

Copyright for this article is retained by the author, with first publication rights granted to the journal.

This is an open-access article distributed under the terms and conditions of the Creative Commons Attribution license (http://creativecommons.org/licenses/by/4.0/). 